\title{
Water Quality Management of the Waters of the Romanian River Hârtibaciu
}

\author{
Daniela Maria Șandru \\ "Lucian Blaga" University from Sibiu, Romania \\ e-mail: danielaraulea@yahoo.com
}

Keywords: Hârtibaciu River, $\mathrm{CBO}_{5}, \mathrm{CCOCr}$, heavy metals

\begin{abstract}
This study aims at monitoring physico-chemical features of the waters of the Hârtibaciu River in Romania with a view to establishing its qualitative benchmarks. Using the waters of this river for agricultural purposes leads to the establishment of its physical and chemical features and its falling within the related quality group. This study has monitored general chemical indicators and specific chemical indicators in the waters of the Hârtibaciu River; the resulting values show that it falls within the $2^{\text {nd }} / 3^{\text {rd }}$ quality group.
\end{abstract}

\section{INTRODUCTION}

Rivers are the main source of drinking and industrial water in Romania. They are characterized by flowing phenomena (which incfluences the amount of suspended or colloidal particles, physical and chemical features, the shape of the river bed, the variation of the water flow and level), the contact surface between water and atmosphere (which influences oxygenation capacity, daily and seasonal temperature variation) and the self-purifying capacity (Oprean et al. 2007, Iancu et al. 2013, Maher et al., 1999). A sustainable water management leads to the establishment of important benchmarks in order for water sources that are necessary for agriculture and for the perpetuation of fish and other aquatic living creatures to be used in proper conditions (Pylea et al. 2005).

Rivers are characterized by the presence of natural impurities. The specific structure depends on the soils along the river bed, the soils in the drainage basin, the waste waters discharged by various users and the capacity to dissolve atmospheric gases.

The rivers and tributaries present a lower degree of mineralization; the amount of dissolved mineral salts is under $400 \mathrm{mg} / \mathrm{L}$ and is made up of bicarbonates, chlorides, nitrates, phosphates, Sodium, Potasium, Calcium and Magnesium sulphates coming from the erosion of rocks, soil and precipitation.

Generally, metals represent both a soil (irrigations) and a water contamination problem. Thus, it is mandatory to include a close monitorization in their quality control strategy (Osibanjo et al. 2011, Singare 2011, Prabha et al. 1997, Sharma et al. 2004).

The main characteristic of watercourses is the variable load of suspended and colloidal particles (clays, sand, silica) and organic substances. When it rains, this load increases considerably (Oancea et al. 2007).

The discharge of effluents that are insuficiently treated has led to the alteration of watercourse quality and to the emergence of a wide range of impurifiers: non-rapidly degradable organic substances, sulphur, nitrate, phosphorus compounds, microelements (copper, zinc, lead), pesticides, organic chorinated insecticides, detergents etc. (Oprean et al. 2008, Oprean et al.2013, Nyugen et al. 2005, Lee et al. 2000).

In several cases, high bacteriological impurities can be observed. Microorganisms, viruses, protozoa originate from the discharging of waste waters that were contaminated with human or animal waste, microorganisms from the ecosystem (Stegăruș et al. 2013).

River waters have a self-purifying capacity, due to natural biochemical processes favoured by the contact between air and water; nevertheless, bacteriological contamination does not fade (Schriever et al. 2010, Medema et al. 2006 ). 
Self-purification or natural purification refers to all the natural purification processes through which water is restored to the qualitative level before it was polluted. Environmental, chemical, physical and biological factors facilitate the process of self-purification.

\section{MATERIALS AND METHODS}

Water samples taken from 6 places (noted P1, P2, P3, P4, P5, P6) between the city of Agnita and the commune of Nocrich (Transylvania, Romania).

The physico-chemical analysis focused on the following parameters; the methods employed are in accordance with Order no. 161/2006 - Normative regarding the classification of surface waters to establish the ecological status of water bodies.

- CCOCr, (SR ISO 6060/1996)

- $\mathrm{CBO}_{5}$, (SR EN 1899/1,2-02,03,DIN 38409-87)

- CCOMn, (SR EN ISO 8467-01)

- dissolved $\mathrm{O}_{2}$ (SR EN ISO 25814-99)

One parameter that plays an important part in water analysis is the Chemical Oxygen Demand (COD). This determination offers precious information on the level of water pollution with organic matter.

- nitrogen, in the form of ammonium, is the basic indicator that highlights the degree of organic nitrous pollution of wasterwaters. It is determined in accordancw with SR ISO 7150/1-00, nitrates are determined in accordance with SR ISO 7890-3/2000 and nitrites in accordance with SR ISO $26777 / 06$.

- heavy metals (As, $\mathrm{Ba}^{2+}, \mathrm{Cd}^{2+}, \mathrm{Cu}^{2+}, \mathrm{Cr}^{6+}, \mathrm{Hg}^{2+}, \mathrm{Pb}^{2+}$ )

Heavy metals are natural compounds that cannot be broken down or destroyed; in high concentrations, they are toxic and dangerous. Metals get in the human body in the form of cations (iron, manganese, cobalt, copper, molybdenum, zinc) and light metals (potassium, calcium, magnesium and sodium).

The above-mentioned metals were determined through the agreed method SR EN ISO 15586/2004 "Water quality - Determination of trace elements using atomic absorption spectrometry with graphite furnace".

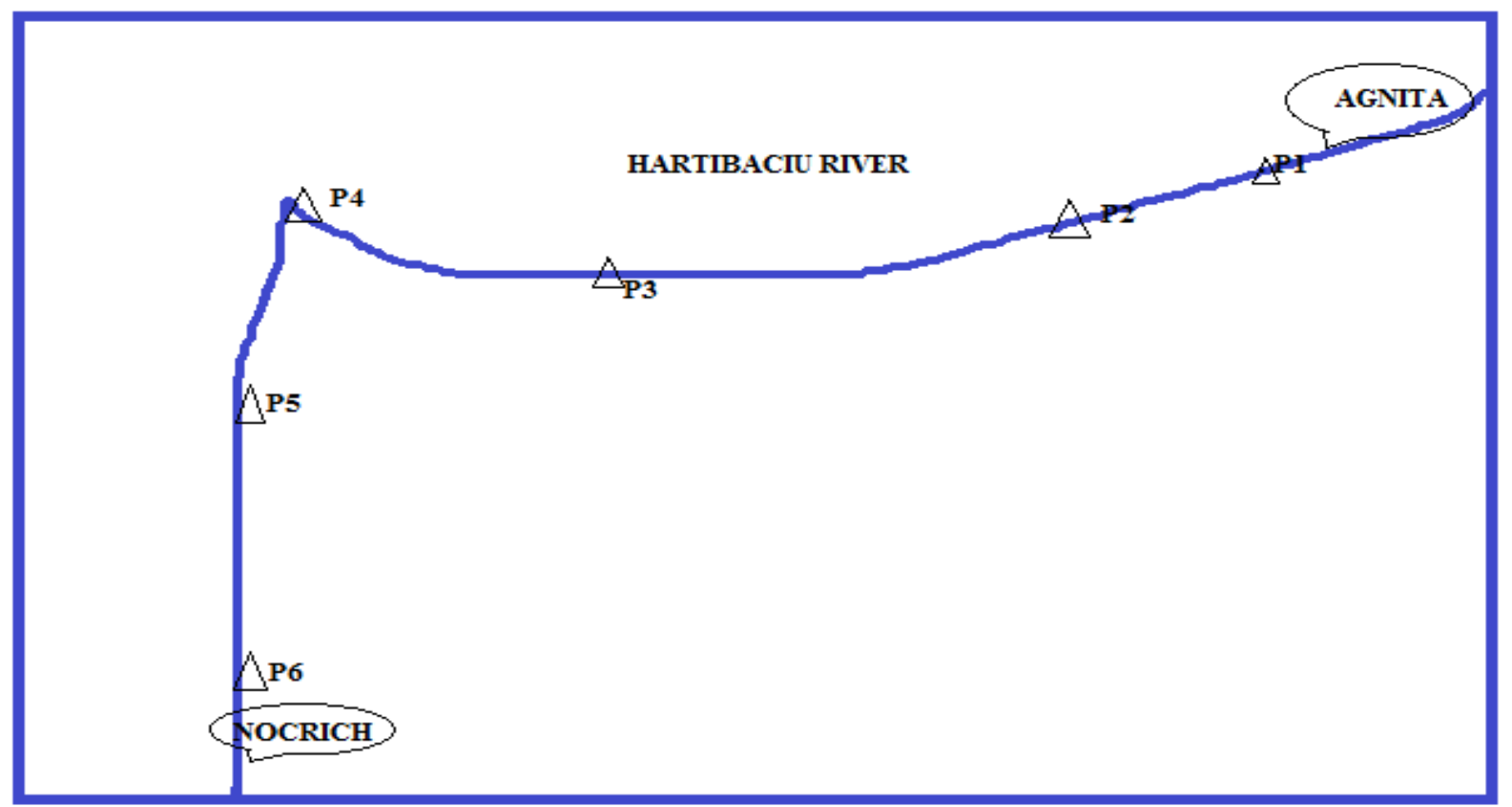

Figure 1. Hârtibaciu River on the segment Agnita-Nocrich with the places where the water samples were taken 


\section{RESULTS AND DISCUSSIONS}

As shown in Figure 2, the determined amounts of ammonium fall between $1.98 \mathrm{mg} / \mathrm{L}$ at collection point $\mathrm{P} 3$ and $2.79 \mathrm{mg} / \mathrm{L}$ at collection point $\mathrm{P} 6$; the maximum values fall within the quality group. Nitrates recorded concentrations between $13.67 \mathrm{mg} / \mathrm{L}$ at collection point P3 and a maximum of $22.11 \mathrm{mg} / \mathrm{L}$ at collection point P6. Nitrites recorded a minimum value of $1.17 \mathrm{mg} / \mathrm{L}$ at collection point $\mathrm{P} 3$ and a maximum of $3.01 \mathrm{mg} / \mathrm{l}$ at collection point $\mathrm{P} 1$. The values recorded by the "nutrient" group fall within the quality group of surface waters.

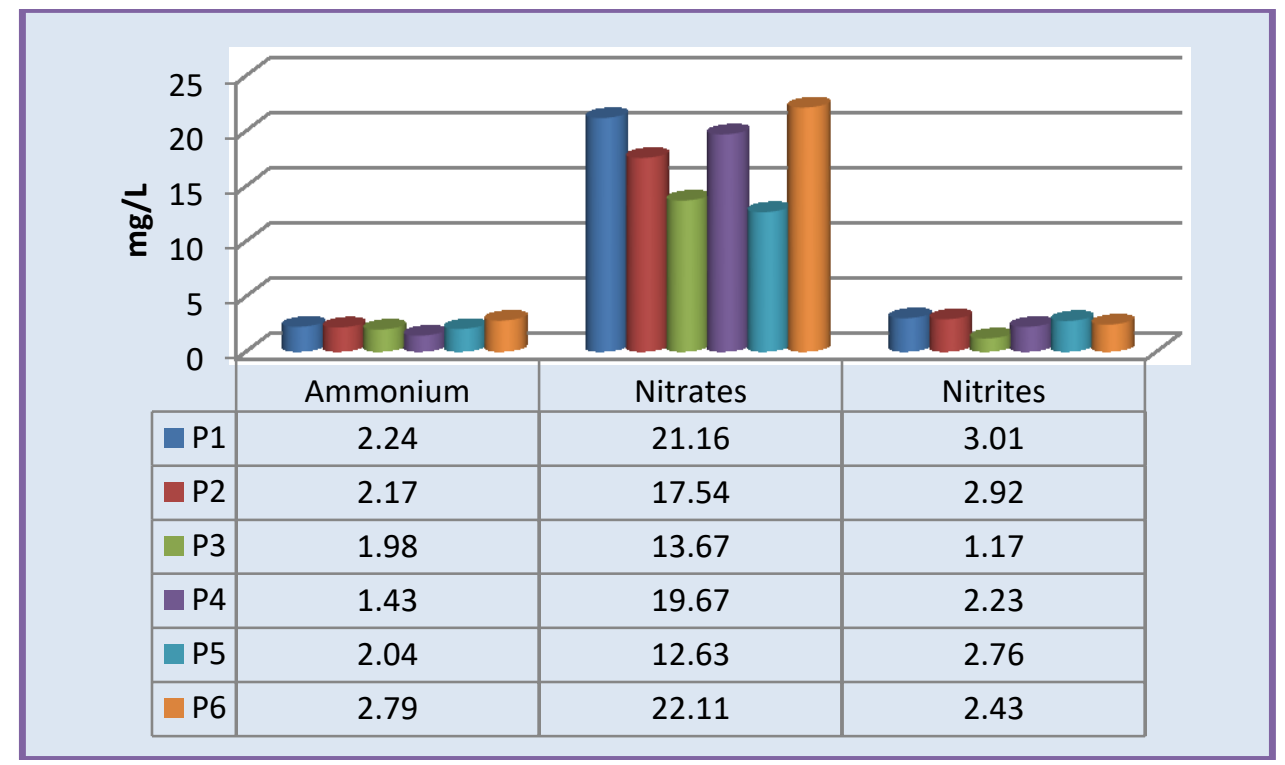

Figure 2. Concentrations of ammonium, nitrates and nitrites recorded in the six water collection points on the Hârtibaciu River

The indicators of Oxygen regime (Figure 3) recorded the following values: dissolved oxygen recorded values between a minimum of $4.83 \mathrm{mg} / \mathrm{L}$ at collection point $\mathrm{P} 4$ and a maximum of 5.13 $\mathrm{mg} / \mathrm{L}$ at collection point P6. The results of the biochemical oxygen demand recorded values between $6.19 \mathrm{mg} / \mathrm{L}$ at collection point $\mathrm{P} 1$ and $7.34 \mathrm{mg} / \mathrm{L}$ at collection point $\mathrm{P} 2$. Collection points $\mathrm{P} 3$ and P6 recorded close values that oscillate around $7.17 \mathrm{mg} / \mathrm{L}$ and $7.12 \mathrm{mg} / \mathrm{L}$ respectively. The CCCOMn values recorded were $12.52 \mathrm{mg} / \mathrm{L}$ at collection point $\mathrm{P} 2,12.58 \mathrm{mg} / \mathrm{L}$ at collection point $\mathrm{P} 5$ and a maximum of $13.61 \mathrm{mg} / \mathrm{L}$ at collection point $\mathrm{P} 3$, respectively $13.44 \mathrm{mg} / \mathrm{L}$ at collection point P6. In what regards the chemical oxygen demand determined through the potassium dichromate method showing the concentration of organic substances in the waters of the Hârtibaciu River, it recorded a minimum value of $15.92 \mathrm{mg} / \mathrm{L}$ at collection point $\mathrm{P} 4$ and a maximum value of $18.65 \mathrm{mg} / \mathrm{L}$ at collection point P6. Intermediary values were recorded at collection points P2 (18,45 $\mathrm{mg} / \mathrm{L})$ and $\mathrm{P} 3(18,34 \mathrm{mg} / \mathrm{L})$, values close to the maximum and to $16.23 \mathrm{mg} / \mathrm{L}$ at collection point $\mathrm{P} 1$, respectively $17.44 \mathrm{mg} / \mathrm{L}$ at collection point $\mathrm{P} 5$. 


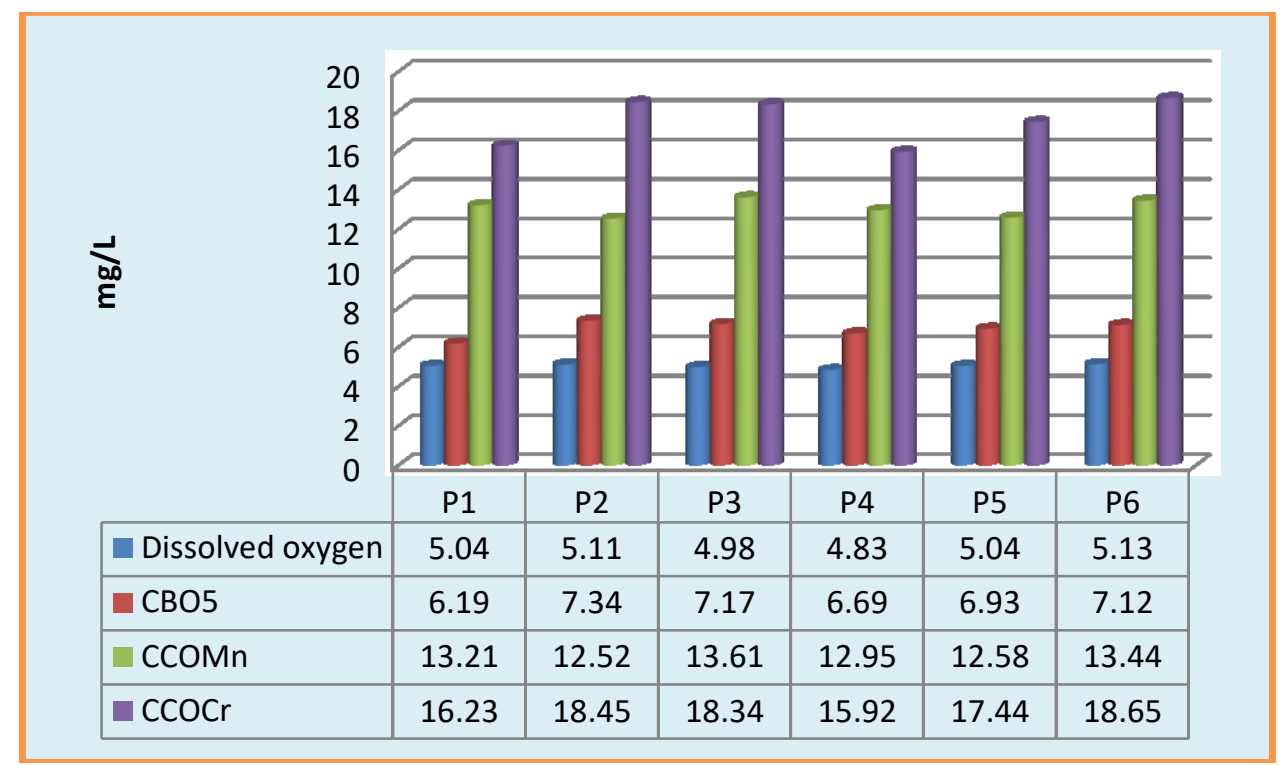

Figure 3. Concentration of dissolved oxygen and biochemical oxygen demand identified in the six water collection points on the Hârtibaciu River

Figure 4 shows the values referring to the metals determined in the waters of the Hârtibaciu River; these values contribute to its falling into the related quality group. We can notice that arsenic recorded values between 7,2 $\mu \mathrm{g} / \mathrm{L},(\mathrm{P} 5)$ and $12 \mu \mathrm{g} / \mathrm{L}$ (P4). P1 recorded a value of $8,3 \mu \mathrm{g} / \mathrm{L}$, close to that of P3 - 8,1 $\mu \mathrm{g} / \mathrm{L}$. Barium recorded the following values: P1-79,21 $\mu \mathrm{g} / \mathrm{L}<\mathrm{P} 5-81,21 \mu \mathrm{g} / \mathrm{L}, \mathrm{P} 6-$ $66,72 \mu \mathrm{g} / \mathrm{L}<\mathrm{P} 2-77,12 \mu \mathrm{g} / \mathrm{L}$, and $\mathrm{P} 4-12,3 \mu \mathrm{g} / \mathrm{L}<\mathrm{P} 3-45,73 \mu \mathrm{g} / \mathrm{L}$. We can see barium reached a maximum level of $81,21 \mu \mathrm{g} / \mathrm{L}$ and a minimum value of $12,3 \mu \mathrm{g} / \mathrm{L}$.

The values recorded in the case of an important indicator, cadmium, were situated between $27 \mu \mathrm{g} / \mathrm{L}$ at collection point $\mathrm{P} 4$ and a maximum of $0,69 \mu \mathrm{g} / \mathrm{L}$ at collection point P6. Values close to those recorded at collection point P6 were measured at collection point P1, i.e. $0,67 \mu \mathrm{g} / \mathrm{L}$. At collection points P2 and P3 we recorded values of $0,47 \mu \mathrm{g} / \mathrm{L}$, respectively $0,55 \mu \mathrm{g} / \mathrm{L}$.

Hexavalent chromium identified in the six water samples taken from the Hârtibaciu River recorded values between $2,8 \mu \mathrm{g} / \mathrm{L}$ - P5 and a maximum of 6,9 - P4. Values $20 \%$ lower than the maximum were measured at collection point $\mathrm{P} 2$ and values $38 \%$ lower at collecting point $\mathrm{P} 1$. Copper, a metal that is permanently identified in surface waters recorded values of 3,8 $\mu \mathrm{g} / \mathrm{L}$ in samples P3 and P6 and $5,4 \mu \mathrm{g} / \mathrm{L}$ in $\mathrm{P} 1$ and respectively $5,9 \mu \mathrm{g} / \mathrm{L}$ in $\mathrm{P} 5$.

The maximum copper values recorded were $3 \mu \mathrm{g} / \mathrm{L}$ in the sample taken at collection point $\mathrm{P} 4$ and $7,6 \mu \mathrm{g} / \mathrm{L}$ the one taken at collection point $\mathrm{P} 2$. Mercury presented sub-unit values in all the samples, i.e. between $0,45 \mu \mathrm{g} / \mathrm{L}$ and a maximum of $0,91 \mu \mathrm{g} / \mathrm{L}$. Intermediary values were recorded in the samples taken from collecting points P1-0,56 $\mu \mathrm{g} / \mathrm{L}, \mathrm{P} 3-0,83 \mu \mathrm{g} / \mathrm{L}, \mathrm{P} 4-0,72 \mu \mathrm{g} / \mathrm{L}$. Lead, a metal that is highly toxic for the soil and the human body, recorded values between $22,1 \mu \mathrm{g} / \mathrm{L}$ in sample P4 and $46,7 \mu \mathrm{g} / \mathrm{L}$ in sample P5. Values close to the maximum were also recorded at collection point $\mathrm{P} 1$, where the amount was $46,6 \mu \mathrm{g} / \mathrm{L}$. At collection point $\mathrm{P} 3$, the amount of lead was $10 \%$ lower than at collection point $\mathrm{P} 2$. 


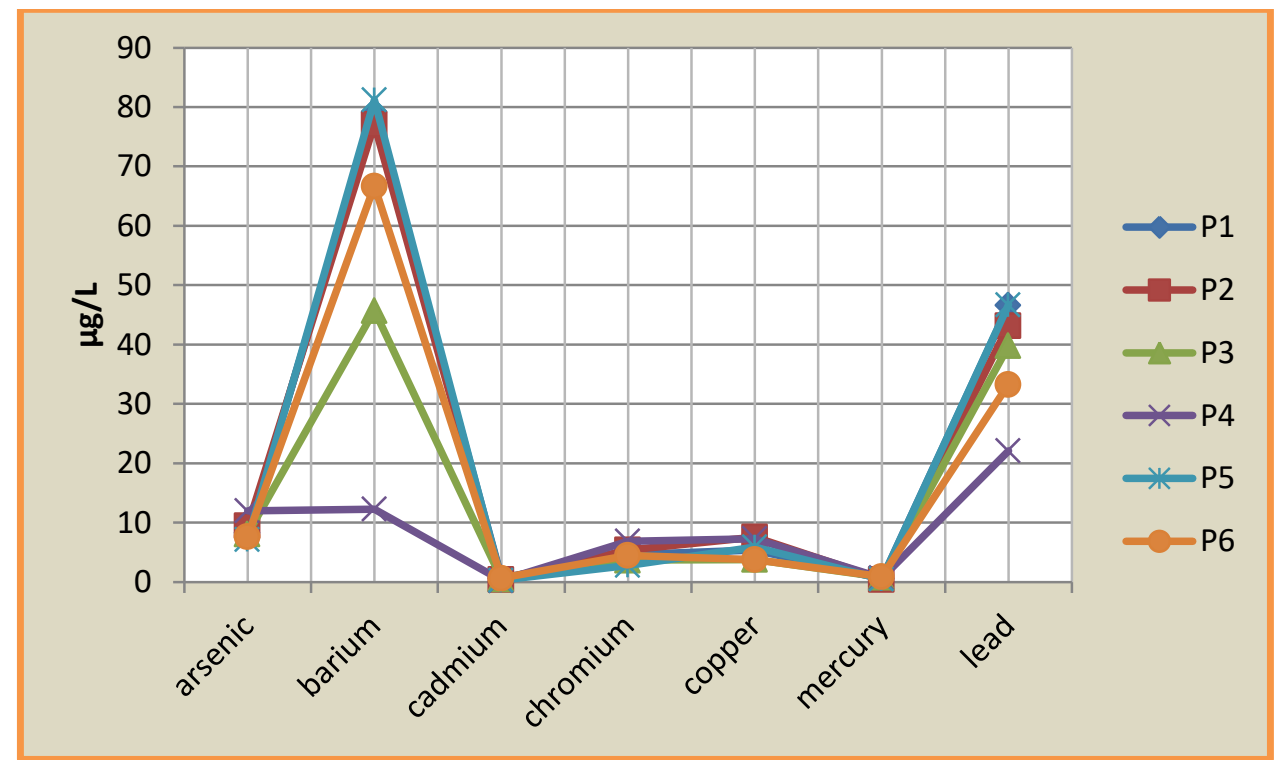

Figure 4. Concentration of metals in the six water collection points on the Hârtibaciu River

\section{CONCLUSIONS}

From the point of view of nutrients, the values measured in the waters of the Hârtibaciu River fall within the $2^{\text {nd }}$ quality group, which means they are recommendable for agricultural purposes.

Oxygen regime indicates a high concentration of organic matter; from this point of view the waters fall within the $3^{\text {rd }}$ quality group. This can also be explained by the lack of sewerage systems upstream of the city of Agnita, as nearby villages frequently discharge household waste into the outfall.

The metals do not pose a danger to the quality of these waters, also given the lack of a high level of industrialization in the area; according to the values recorded, the waters fall within the $2^{\text {nd }}$ quality group.

\section{References}

[1] Iancu, R., Letiţia Oprean, Diana Stegăruş, Ovidiu Tiţa, Adrian Boicean, Ecaterina Lengyel,(2013), Environmental indicators of water quality in the Cibin River, Romania, Transylvanian Review of Systematical and Ecological Research - The Wetlands Diversity $2013,91-106$,

[2] Lee, B. G., Griscom, S. B., Lee, J. S., Choi, H. J., Koh, C. H., Luoma, S. N., and Fisher, N. S., 2000, Influence of dietary uptake and reactive sulfides on metal availability from aqua-tic sediments., Science, 287(5451), 282-284

[3] Maher, W., Batley, G. E., and Lawrence,I., 1999, Assessing the health of sediment ecosystems: use of chemical mea-surements., Freshw Biol., 41(2),361-372

[4] Medema G, Loret JC, Stenström TA, Ashbolt N (2006). Quantitative Microbial Risk Assessment in the Water Safety Plan. Final Report on the EU MicroRisk Project. Brussels: European Commission. Pp 1-36

[5] Nguyen, H., M. Leermakers, J. Osan, S. Tfrfk and W. Baeyens. 2005. Heavy metals in Lake Balaton: water column, suspended matter, sediment and biota. Science Of the Total Environment. 340: 213-230.

[6] Oancea, S., Letiţia Oprean, Ecaterina Lengyel, Monica Goncea, Enikő Gaspar, Mihaela Stoia, Mariana Păcală, (2008), Characterization of heavy metals pollutants in the sewage sludge produced at Sibiu WWTP and perspectives on its agricultural utilizations, Acta Universitatis Cibiniensis, seria F Chemia, vol 11 (1), ISSN 1583-5030, 47-52, 
[7] Oancea,Simona Letitia Oprean, Eniko Gaspar, Ecaterina Lengyel, Study on some toxic parameters level of waters and sediments sampled from the river Cibin upstream and downstream of the waste waters spill, IND ECOIND, International symposium ,vol.I 2007, p.323-328,ISSN 1843-5831

[8] Oprean Letitia, Gaspar Eniko, Mironescu Monica, Camelia Oprean,Oancea Simona, Lengyel Ecaterina,(2007), The degree of pollution regarding the Cibin river, IND ECOIND, International symposium, vol.I 335-341, ISSN 1843-5831,.

[9] Oprean, L., Dan Chicea, Eniko Gaspar, Ecaterina Lengyel,(2008) Result of physical and chemical parameters monitoring of the Raul Mare river, Romanian Journal of Physic, Vol 53, Nos. 7-8, 947-953,

[10] Oprean, L., Ecaterina Lengyel and Ramona Iancu, (2013) Monitoring and evaluation of Timiş River water quality based on physicochemical and microbiological analysis Transylvanian Review of Systematical and Ecological Research-Timiş River Basin 2013, 23-32, [11] Osibanjo,O. Daso A P. and Gbadebo A M. (2011) The impact of industries on surface water quality of River Ona and River Alaro in Oluyole Industrial Estate, Ibadan, Nigeria Afr. J. Biotechno. 10 (4): 696-702,

[12] Singare, P.U. Heavy metal -- in and around the lakes- Pollu-tion due to toxic heavy metals at the Jail Talav and Kalwa Lakes of Thane City, EurekAlert!-Atmospheric Science - Sunday, August 7, 2011. [Online].

[13] Prabha, S., and Selvapathy, P., 1997, Heavy metal pollution in Indian Rivers., Indian J. Environ. Prot., 17(6), 641-649

[14] Pylea, G., W. J. Rajotteb and P. Couturec. 2005. Effects of industrial metals on wild fish populations along a metal contamination gradient. Ecotoxicology and Environmental Safety, 61 (2005), 287-312.

[15] Schriewer A, Miller WA, Byrne BA, Miller MA, Oates S, Hardin D, Yang HH, Melli A, Jessup D, Dominik C, Wuertz S (2010). Presence of Bacteroidales as a predictor of pathogens in surface waters of the Central California Coast. Appl Environ Microbiol, 76(17): 5802-14.

[16] Sharma, R. K., Agrawal, M., and Marshall, F. M., 2004, Effects of waste water irrigation on heavy metal accumulation in soil and plants., Paper presented at a National Seminar, Bangalore University, Bangalore, Abst. no. 7, pp. 8

[17] Stegarus, D.,Claudia Sandru, Ioan Stefanescu, Ovidiu Tita, Ramona Iancu, Mariana-Liliana Pacala, Ecaterina Lengyel, (2013), The monitoring of the physical-chemical and bacteriological indicators of Cibin river in view of quality classification, Conference proceeding, International Multidisciplinary Scientific Geoconference, SGEM 2013, Albena Bulgaria, Advances in Biotechnology, 1045-1052, 